\title{
Karakteristik Beberapa Jenis Antibiotik Berdasarkan Pola Difraksi Sinar-X (XRD) Dan Spektrum FTIR
}

\author{
${ }^{1}$ Mirzan T. Razzak*, ${ }^{1}$ S. Hermanto, ${ }^{2}$ Priyambodo \\ ${ }^{1}$ Program Studi Kimia Fakultas Sains dan Teknologi, UIN Syarif Hidayatullah Jakarta \\ ${ }^{2}$ Program Studi Fisika Fakultas Sains dan Teknologi, UIN Syarif Hidayatullah Jakarta \\ Jl. Ir. H. Juanda No. 95 Ciputat, Jakarta 15412
}

\begin{abstract}
Abstrak
Telah dilakukan pengukuran karakteristik difraksi sinar-x (XRD) terhadap beberapa jenis antibiotik. Penelitian ini bertujuan untuk memahami karakteristik difraksi sinar-x suatu antibiotik sebagai upaya untuk identifikasi antibiotik secara cepat. Dalam penelitian ini diamati karakteristik difraksi sinar-x dari 15 (lima belas) antibiotik yang tersedia di pasaran. Spektrum XRD diukur pada sudut $2 \theta$ antara $5^{\circ}-75^{\circ}$ untuk dibandingkan dan dievaluasi mengenai bentuk kristalnya. Selanjutnya diukur pula spektrum XRD dari pencampuran antibiotik dengan tepung tapioka. Pengukuran spektrum infrared dengan FTIR juga dilakukan untuk menguji konsistensi hasil evaluasi spektrum XRD. Hasil penelitian menunjukkan bahwa amoxicillin dan ampicillin mempunyai struktur kristal yang sama, yaitu orthorombic primitif. Sayangnya baik XRD maupun FTIR, tidak memberikan nilai kuantitatif pada antibiotik. Oleh sebab itu, perbedaan konsentrasi dengan pencampuran tepung tapioka tidak dapat dideteksi. Walaupun demikian, metode ini terbukti dapat digunakan untuk membedakan komposisi zat penyusun antibiotik secara cepat dan akurat.
\end{abstract}

Kata kunci: antibiotik, tapioka, difraksi-sinar-x (XRD), Fourier Transform Infrared (FTIR)

\begin{abstract}
The measurement of x-ray diffraction characteristic of various antibiotics has been done. The aim of measurement is to understand the characteristic of antibiotic as well as to identifying antibiotic by a faster manner. In this research, fifteen (15) antibiotics which are available in market were investigated. XRD spectra were measured from angle $2 \theta$ of $5^{\circ}-75^{\circ}$ and the result were compared and evaluated to obtain crystal structure. The measurement of infrared spectra using FTIR also had been done to exam the consistency of analysis result from XRD spectrum. It was found that amoxicillin and ampicillin show the same crystal structure of a primitive orthorhombic. In addition, both the XRD and FTIR spectra of all other measured antibiotics were very specific for respective antibiotic. Unfortunately, the spectra do not inform quantitatively the concentration of antibiotic, where after the amount of treated mixture such as tapioca powder which is probably contaminated to the antibiotic could not be detected. However, these method proofs can be used as to distinguish composition of antibiotic faster and accurately.
\end{abstract}

Keywords: antibiotic, tapioca, x-ray diffraction (XRD), Fourier Transform Infrared (FTIR)

\section{PENDAHULUAN}

Antibiotik merupakan senyawa kimia yang sangat penting dalam bidang kedokteran terutama digunakan untuk menyembuhkan penyakit yang disebabkan oleh infeksi bakteri di dalam tubuh manusia. Menurut definisi, antibiotik adalah senyawa kimia organik yang mampu membunuh atau menghambat pertumbuhan bakteri (1).
Antibiotik jenis bakterisida (pembunuh bakteri) umumnya digunakan untuk mengobati infeksi bakteri dimana penderita biasanya memiliki sistem kekebalan (immune) yang rendah. Antibiotik yang masuk golongan ini diantaranya $\beta$-lactam, aminoglycoside, dan fluoroquinole $(2,3)$. Sedangkan antibiotik jenis bakteriostatik (penghambat pertumbuhan) dapat digunakan oleh penderita yang memiliki sistem pertahanan tubuh yang normal untuk 
membantu menghancurkan mikroorganisme. Antibiotik yang masuk golongan ini diantaranya tetracycline, sulfonamides, clindamycin, dan chloramphenicol $(1,4,5)$.

X-Ray diffraction (XRD) adalah teknik analitik yang sesuai untuk menguji kristal zat padat, seperti keramik, logam, materi elektronik, materi geologi, organik, dan polimer. Materi tersebut dapat berupa serbuk, kristal tunggal, film tipis dengan banyak lapisan (multilayer thin-film), lembaran, serat (fiber), atau materi dengan bentuk tak beraturan (6). Sistem kristal yang dimiliki oleh suatu materi menurut Bravais dapat dilihat pada Tabel 1.

Tabel 1. Unit sel menurut 14 kisi Bravais

\begin{tabular}{|c|c|c|c|c|}
\hline Crystal System & $\begin{array}{l}\text { Primitive } \\
(\mathrm{P})\end{array}$ & $\begin{array}{l}\text { Body-Centered } \\
\text { (I) }\end{array}$ & $\begin{array}{c}\text { Face-Centered } \\
\text { (F) }\end{array}$ & $\begin{array}{l}\text { End-Centered } \\
\text { (C) }\end{array}$ \\
\hline $\begin{array}{l}\text { Cubic } \\
a=b=c \\
\alpha=\beta=\gamma=90^{\circ}\end{array}$ & & & & \\
\hline $\begin{array}{l}\text { Tetragonal } \\
a=b \neq c \\
\alpha=\beta=\gamma=90^{\circ}\end{array}$ & & & & \\
\hline $\begin{array}{l}\text { Orthorhombic } \\
a \neq b \neq c \\
\alpha=\beta=\gamma=90^{\circ}\end{array}$ & & & & \\
\hline $\begin{array}{l}\text { Hexagonal } \\
a=b \neq c \\
\alpha=\quad \beta=90^{\circ} ; \\
\gamma=120^{\circ}\end{array}$ & & & & \\
\hline $\begin{array}{l}\text { Trigonal } \\
\text { (Rhombohedral) } \\
\mathrm{a}=\mathrm{b}=\mathrm{c} \\
90^{\circ} \neq \alpha=\beta= \\
\gamma<120^{\circ}\end{array}$ & & & & \\
\hline $\begin{array}{l}\text { Monoclinic } \\
a \neq b \neq c \\
\alpha=\gamma=90^{\circ} ; \beta>90^{\circ}\end{array}$ & & & & \\
\hline $\begin{array}{l}\text { Triclinic } \\
a \neq b \neq c \\
\alpha \neq \beta \neq \gamma\end{array}$ & & & & \\
\hline
\end{tabular}

Prinsip dasar yang digunakan untuk menentukan sistem kristal adalah dengan menggunakan persamaan hukum Bragg:

$$
2 d \sin \theta=n \lambda
$$

dimana $d$ adalah jarak antar-bidang kisi, $\theta$ adalah sudut pengukuran, $n$ adalah indeks, sedangkan $\lambda$ adalah panjang gelombang sumber sinar-x (7). Penelitian dengan XRD untuk identifikasi senyawa organik terutama antibiotik sudah banyak dilakukan, diantaranya oleh Thomas R.M.Barends dkk. (8), S.Thangadurai dkk.(9), dan Shinobu dkk. (10). Informasi ini menunjukan bahwa teknik ini dapat digunakan juga untuk meneliti karakteristik antibiotik. 
Spektrometri infrared telah berkembang secara pesat selama 40 tahun terakhir. Teknik spektrometri infrared digunakan untuk penentuan struktur senyawa-senyawa organik. Teknik ini biasanya digabung dengan teknik Nuclear Magnetic resonance (NMR), Spektrometer massa, bahkan digabung dengan XRD (11).

Perkembangan teknik sampling pada spektroskopi infrared saat ini dan dilengkapinya FTIR dengan Attenuated Total Reflectance (ATR) maka pengukuran spektrum infrared dari berbagai sampel dapat dilakukan secara lebih mudah.Teknik FTIR sudah berhasil digunakan untuk menentukan residu petrolium (11), spesifikasi karbon organik di dalam tanah (12), komposisi keju (13), struktur protein (14), dan identifikasi bakteri (15). Berbagai studi telah menunjukkan bahwa spektroskopi FTIR dapat memberikan informasi karakteristik struktural suatu senyawa organik makromolekul. Oleh karena itu, pada penelitian ini juga digunakan teknik FTIR dalam karakteristik senyawa organik antibiotik.

\section{METODE PENELITIAN}

\section{Bahan}

Pada penelitian ini digunakan 15 jenis antibiotik dari berbagai golongan yang diperoleh dari apotik di kawasan Jakarta. Antibiotik tersebut terdiri dari golongan $\beta$ lactam, fluoroquinones, lincosamides, sulphonamides, tetracycline, dan macrolides. Kelima belas jenis antibiotik tersebut adalah :

- acyclovir (GKL9520918210A1)

- amoxicillin (GKL9312412804A1)

- ampicilin (GKL8920909904A1)

- cefadroxyl (GKL9320916101B1)

- chloramphenicol (GKL9420906501A1)

- ciprofloxacin (GKL9605020017B1)

- clavamox (DKL9111615217B1)

- clindamycin (GKL9720922101A1)

- cotrimoksazole (GKL9130003210A1)

- doxycycline (GKL8920908501A1)

- erythromycin (GKL9320916909A1)

- rovamycin (DKL0121200417A1)

- $\quad$ spiramycin (GKL9820922810B1)

- tetracycline (GKL9812405701B1)

- thiamphenicol (GKL9620920301B1).
Tepung tapioka (tepung kanji) digunakan sebagai bahan pencampur antibiotik. Pencampuran ini bertujuan untuk mengamati apakah terjadi perubahan pola spektrum XRD dan FTIR apabila antibiotik dicampur dengan tapioka. Tepung tapioka tersebut diproduksi oleh PT Budi Acid Jaya Tbk. dengan merek dagang Rose Brand dan nomor produksi MD 22308011011.

\section{Metodologi}

Pengukuran karakteristik difraksi sinar-X pada antibiotik dilakukan dengan XRD 7000 buatan Shimadzu. Peralatan ini dilengkapi dengan goniometer horisontal dan sumber sinar-x yang berasal dari $\mathrm{Cu}\left(\lambda_{\mathrm{K} \alpha}=\right.$ $1,54060 \AA ̊)$. Kalibrasi dilakukan dengan pengukuran karakteristik difraksi sinar-x pada silikon ( $\mathrm{Si}$ ) dengan kemurnian $99 \%$. Sampel serbuk dipadatkan dan diratakan permukaannya pada holder aluminium untuk selanjutnya dilakukan pengukuran. Mode scanning yang digunakan adalah continuos scan pada sumbu 2theta/theta. Antibiotik dan campurannya diukur pada sudut $5^{\circ}-75^{\circ}$, kenaikan sudut $0,02^{\circ}$ dan kecepatan scan $2 \%$ menit. Tegangan operasi adalah $40 \mathrm{kV}$ dan arus $30 \mathrm{~mA}$. Parameter untuk divergence slit, scattering slit, dan receiving slit berturutturut adalah $1,0^{\circ} ; 1,0^{\circ} ;$ dan $0,15^{\circ}$.

Spektrum infrared diperoleh melalui pengukuran dengan peralatan FTIR Spectrum One buatan Perkin Elmer. Sampel berbentuk serbuk dicampur dengan $\mathrm{KBr}$ sampai rata dengan perbandingan 1:100. Setelah tercampur, sampel diletakan pada sampel holder kemudian dipress hingga membentuk suatu lapisan tipis yang rata dan tidak pecah. Pengukuran selanjutnya dilakukan pada rentang bilangan gelombang $4000-450 \mathrm{~cm}^{-1}$.

\section{HASIL DAN PEMBAHASAN}

\section{Spektrum XRD Antibiotik}

Pada Gambar 1 dapat dilihat spektrum XRD pada amoxicillin dan ampicillin. Gambar tersebut menunjukkan bagaimana hubungan antara pengukuran intensitas (cps) terhadap sudut $2 \theta$. Pada amoxicillin terlihat tiga puncak intensitas terkuat yang terjadi pada sudut $2 \theta$ sebesar $15,144^{\circ} ; 18,045^{\circ}$; dan $19,350^{\circ}$ sedangkan pada ampicillin terjadi pada sudut $15,193^{\circ} ; 18,133^{\circ}$; dan $12,341^{\circ}$. 

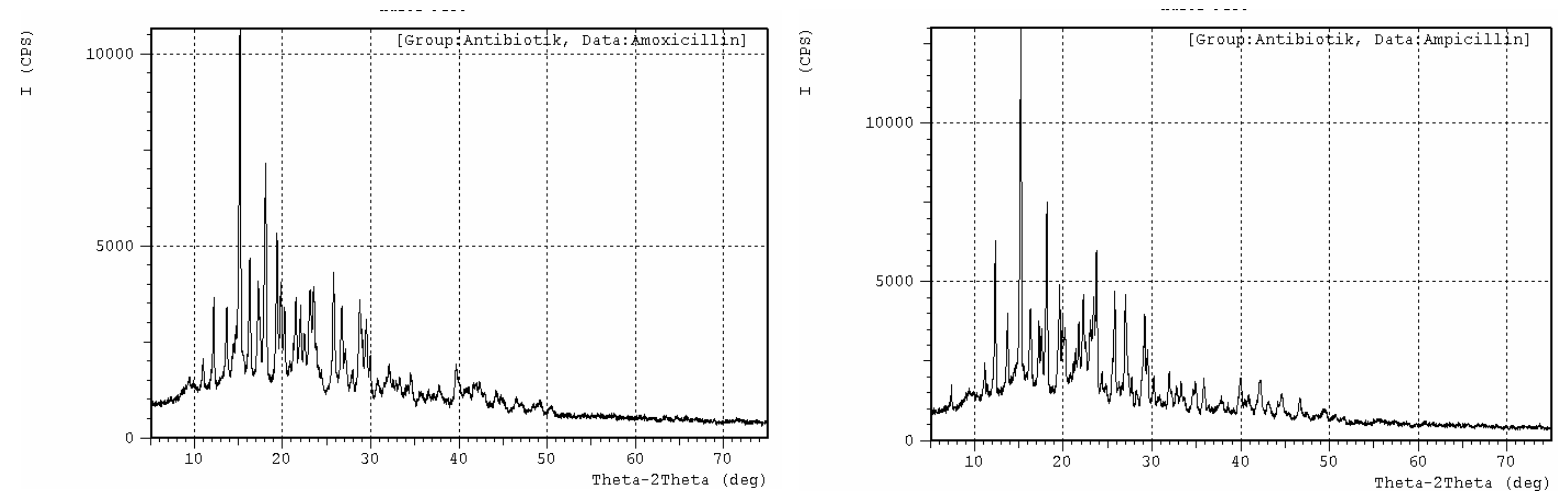

Gambar 1. Spektrum XRD pada antibiotik

Setelah dilakukan perhitungan dengan komputer, maka diperoleh informasi bahwa amoxicillin mengandung amoxicillin trihydrate yang memiliki sistem kristal orthorhombic dengan unit sel primitif $\left(\mathrm{P} 22_{1} 2_{1}\right)$ dan parameter kisi $\mathrm{a}=15,75$; $\mathrm{b}=18,80$; dan $\mathrm{c}=6,684$. Untuk ampicillin sendiri, ternyata mengandung ampicillin trihydrate. Ampicillin trihydrate memiliki sistem kristal orthorhombic dan unit sel primitif $\left(\mathrm{P} 2{ }_{1} 2_{1} 2_{1}\right)$ sama seperti amoxicillin. Perbedaan kedua antibiotik tersebut terletak pada harga parameter kisi ampicillin, yaitu $a=6,657 ; \quad b=15,48 ;$ dan $c=18,887$. Hasil pengukuran yang diperoleh pada penelitian ini tidak jauh berbeda dengan apa yang sudah dilakukan sebelumnya oleh Tangadurai dkk. (9), Brittain (16), dan Alireza dkk.(17).

Apabila spektrum antibiotik dibandingkan seluruhnya, maka dapat dilihat bahwa posisi sudut $2 \theta$ dari beberapa puncakpuncak intensitas terkuat zat penyusun antibiotik tersebar antara sudut $5^{\circ}$ sampai $50^{\circ}$.

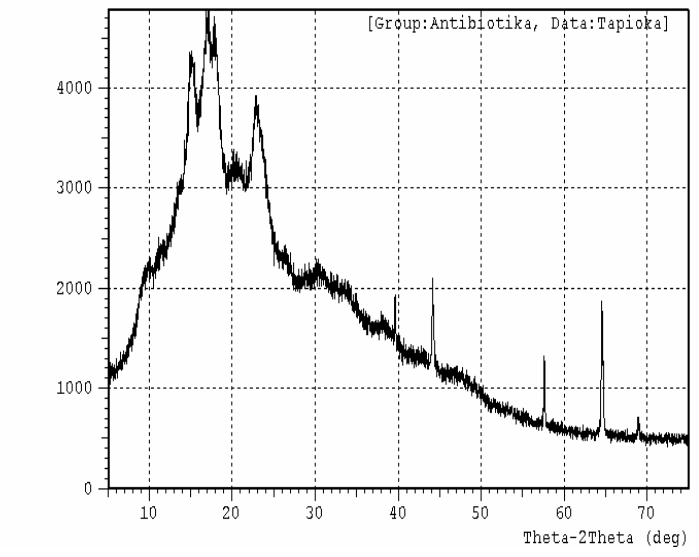

Gambar 2. Spektrum XRD tepung tapioka

\section{Spektrum Tepung Tapioka}

Pada Gambar 2 dapat dilihat spektrum XRD dari tepung tapioka yang digunakan sebagai bahan pencampur antibiotik. Melalui gambar tersebut, terlihat bahwa tapioka memiliki puncak intensitas terkuat pada sudut $2 \theta$ sebesar $16,960^{\circ} ; 17,860^{\circ}$; dan $15,120^{\circ}$. Beberapa puncak intensitas yang cukup jelas terlihat pada sudut $2 \theta$ sebesar $39,582^{\circ} ; 44,145^{\circ} ; 57,564^{\circ}$; dan $64,517^{\circ}$.

\section{Spektrum Campuran Antibiotik dan Tapioka}

Jika antibiotik dicampur dengan tepung tapioka, maka spektrum yang diperoleh dapat dilihat pada Gambar 3 dan 4. Pada kedua gambar tersebut, puncak intensitas yang menjadi karakteristik antibiotik tetap dapat dilihat.

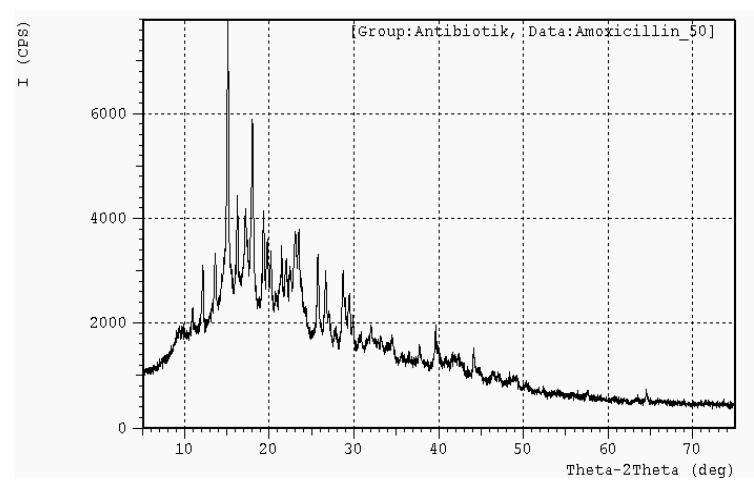

Gambar 3. Spektrum XRD campuran amoxicilin dan tepung tapioka

Pada spektrum campuran amoxicillin dan tepung tapioka (gambar 3), terlihat puncak intensitas terkuat pada sudut $2 \theta$ 
sebesar $15,089^{\circ}$; $17,993^{\circ}$; dan $16,224^{\circ}$. Intensitas spektrum pada sudut $16,224^{\circ}$ lebih tinggi daripada sudut karakteristik antibiotik yang terjadi pada sudut $19,304^{\circ}$. Hal ini terjadi karena tapioka memiliki intensitas tertinggi pada sudut $16,960^{\circ}$ yang dapat dilihat pada Gambar 2. Pada spektrum ini juga terlihat muncul beberapa puncak intensitas tapioka yang terjadi pada sudut $39,620^{\circ} ; 44,124^{\circ}$; dan $64,490^{\circ}$.

Spektrum campuran ampicillin dan tepung tapioka (gambar 4) memperlihatkan puncak intensitas terkuat pada sudut $2 \theta$ sebesar $15,160^{\circ} ; 18,091^{\circ}$; dan $23,670^{\circ}$. Beberapa intensitas spektrum karakteristik tepung tapioka terlihat jelas pada sudut sekitar $40^{\circ}$ ke atas, yaitu sudut $39,940^{\circ}$; $44,580^{\circ}$; 57,605; dan $64,537^{\circ}$.

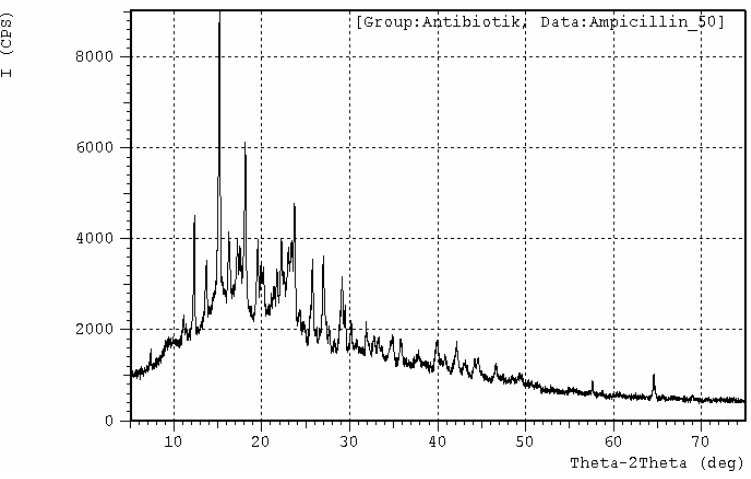

Gambar 4. Spektrum XRD campuran ampicillin dan tepung tapioka

Analisis yang telah dilakukan terhadap spektrum dari 15 jenis antibiotik memberikan hasil bahwa spektrum antibiotik dan campuran antibiotik memiliki pola yang hampir sama. Pencampuran antibiotik dengan tepung tapioka menyebabkan spektrum campuran memiliki garis dasar (baseline) spektrum yang lebih tinggi dan intensitas puncak terkuat menjadi lebih rendah. Perbandingan spektrum difraksi sinar-x pada antibiotik dan campurannya tidak dapat memberikan informasi mengenai konsentrasi zat penyusun antibiotik yang dikandung dalam antibiotik secara kuantitatif.

Analisis yang lain memperlihatkan bahwa setiap materi, khususnya antibiotik memiliki karakteristik spektrum XRD yang berbeda atau spesifik. Perbedaan karakteristik pola spektrum XRD dapat digunakan untuk menganalisis komponen penyusun suatu antibiotik. Spektrum XRD yang diperoleh dari campuran antibiotik dan tepung tapioka memperlihatkkan munculnya puncak intensitas yang menjadi karakteristik antibiotik dan tepung tapioka. Hasil ini menunjukan bahwa pencampuran antibiotik dan tepung tapioka dengan pencampuran biasa tidak menyebabkan perubahan struktur kristal pada antibiotik. Informasi ini menjadi dasar bahwa pengujian XRD dapat digunakan sebagai metode analisis cepat untuk mendeteksi dan membedakan komposisi zat penyusun antibiotik.

\section{Spektrum FTIR Antibiotik Murni}

Pada Gambar 5 dan 6 dapat dilihat bentuk spektrum FTIR dari antibiotik amoxicillin dan ampicillin.

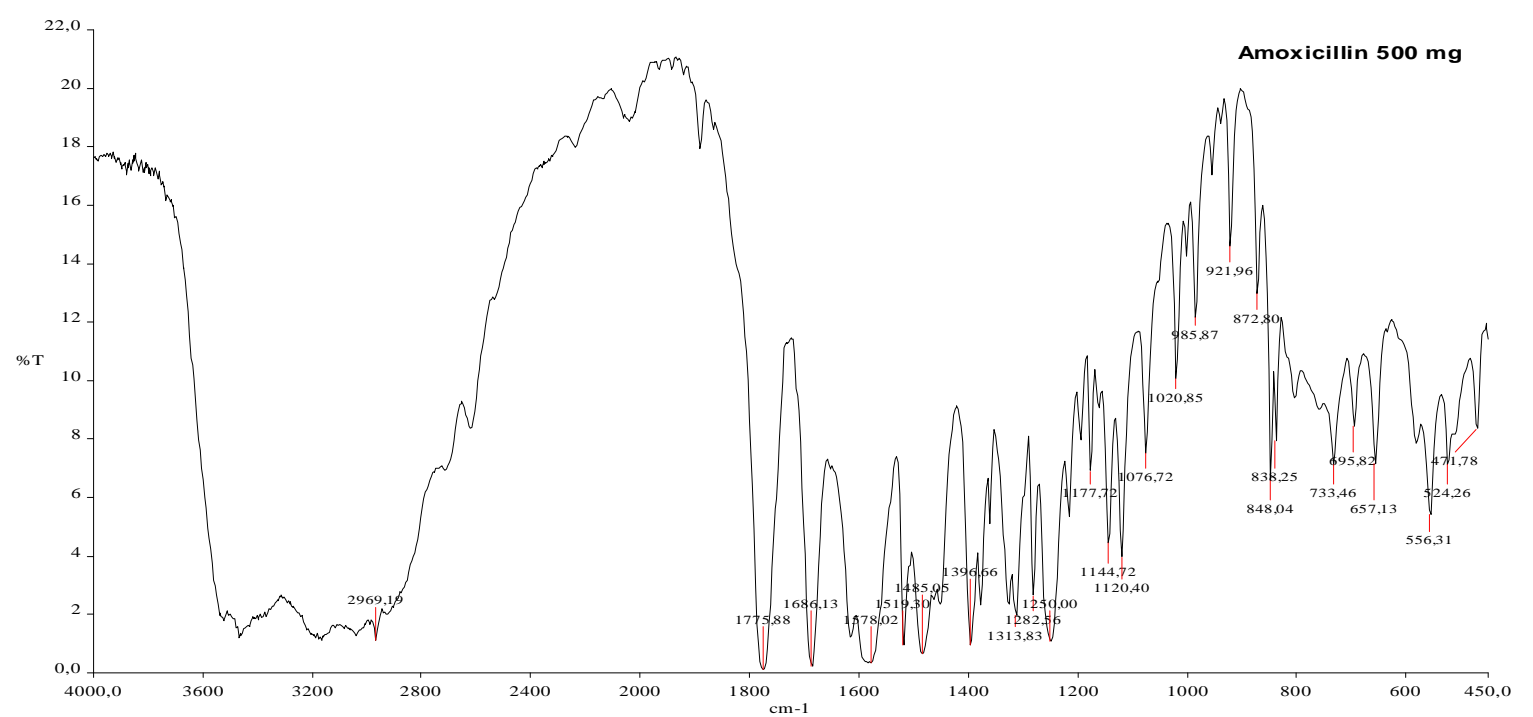

Gambar 5. Spektrum transmittance FTIR antibiotik amoxicilin 


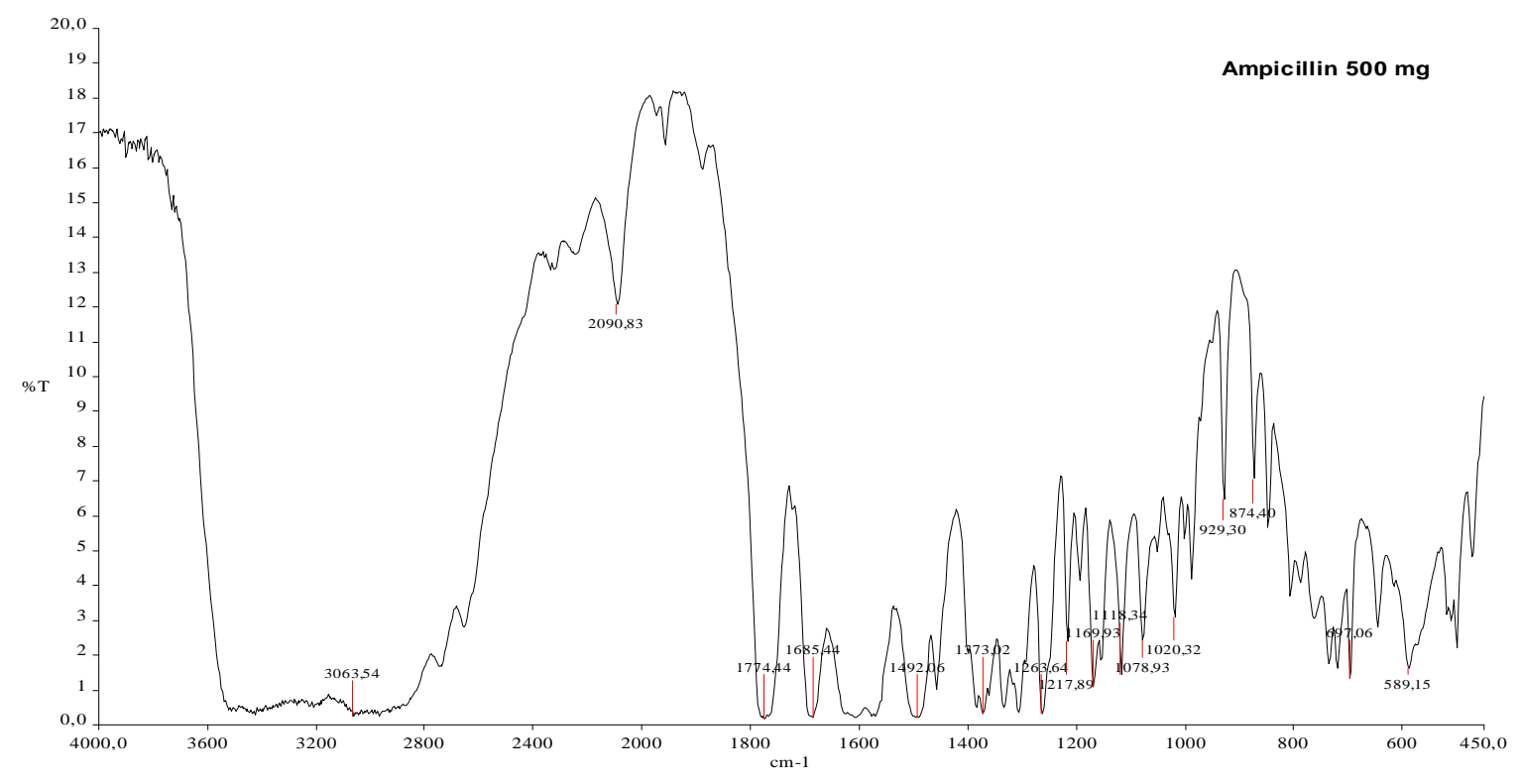

Gambar 6. Spektrum transmittance FTIR antibiotik Ampicillin

Pada spektrum FTIR amoxicillin (gambar 5) terlihat beberapa puncak minimum pada bilangan gelombang tertentu. Puncak pada bilangan gelombang $2969 \mathrm{~cm}^{-1}$ menunjukan stretching vibrasi gugus $\mathrm{O}-\mathrm{H}$; $1775 \mathrm{~cm}^{-1}$ menunjukan stretching vibrasi gugus $\mathrm{C}=\mathrm{O} ; 1686 \mathrm{~cm}^{-1}$ stretching vibrasi $\mathrm{C}=\mathrm{C} ; 1578 \mathrm{~cm}^{-1}$ bending vibrasi $\mathrm{NH} ; 1485$ $\mathrm{cm}^{-1}$ bending vibrasi $\mathrm{C}-\mathrm{H}, 1090-1020 \mathrm{~cm}^{-1}$ untuk stretching vibrasi C-N; $1000-675 \mathrm{~cm}^{-1}$ bending vibrasi $\mathrm{C}-\mathrm{H}$; dan $\quad 556 \mathrm{~cm}^{-1}$ stretching vibrasi $\mathrm{C}-\mathrm{S}$.

Untuk ampicillin (gambar 6) juga terdapat puncak yaitu pada bilangan gelombang $3063 \mathrm{~cm}^{-1}$ yang menunjukan stretching vibrasi gugus $\mathrm{O}-\mathrm{H} ; 1774 \mathrm{~cm}^{-1}$ menunjukan stretching vibrasi gugus $\mathrm{C}=\mathrm{O}$; $1685 \mathrm{~cm}^{-1}$ stretching vibrasi $\mathrm{C}=\mathrm{C} ; 1600 \mathrm{~cm}^{-1}$ bending vibrasi $\mathrm{NH} ; 1350-1000 \mathrm{~cm}^{-1}$ stretching vibrasi $\mathrm{C}-\mathrm{C} ; \quad 1000-675 \mathrm{~cm}^{-1}$ bending vibrasi $\mathrm{C}-\mathrm{H}$; dan pada $589 \mathrm{~cm}^{-1}$ stretching vibrasi $\mathrm{C}-\mathrm{S}$.

Perlu diketahui bahwa bentuk struktur molekul antibiotik dapat dilihat pada Gambar 7. Pada gambar tersebut terlihat jelas bahwa struktur molekul amoxicillin trihydrate hampir sama seperti ampicillin trihydrate. Ampicillin trihydrate tidak mempunyai gugus hydroxy $(\mathrm{OH})$ yang terikat dengan gugus aromatik.<smiles>CC1(C)S[C@@H]2[C@H](NC(=O)[C@H](N)c3ccc(O)cc3)C(=O)N2[C@H]1C(=O)O</smiles>

Amoxicillin trihydrate<smiles>CC1(C)S[C@@H]2[C@H](NC(=O)[C@@H](N)c3ccccc3)C(=O)N2[C@H]1C(=O)O</smiles>

Ampicillin trihydrate

Gambar 7. Contoh Struktur molekul antibiotik

\section{Spektrum FTIR Tepung Tapioka}

Pada spektrum FTIR tepung tapioka (gambar 8) terlihat beberapa puncak minimum pada bilangan gelombang 3392 $\mathrm{cm}^{-1}$ menunjukan stretching vibrasi gugus $\mathrm{O}_{-}$ $\mathrm{H} ; 1650 \mathrm{~cm}^{-1}$ menunjukan stretching vibrasi gugus $\mathrm{C}=\mathrm{O} ; 1364 \mathrm{~cm}^{-1}$ bending vibrasi $\mathrm{C}-\mathrm{H}$; $1017 \mathrm{~cm}^{-1}$ stretching vibrasi $\mathrm{C}-\mathrm{O} ; 860 \mathrm{~cm}^{-1}$ bending vibrasi $\mathrm{C}-\mathrm{H}$; dan $578 \mathrm{~cm}^{-1}$ stretching vibrasi $\mathrm{C}-\mathrm{S}$. 


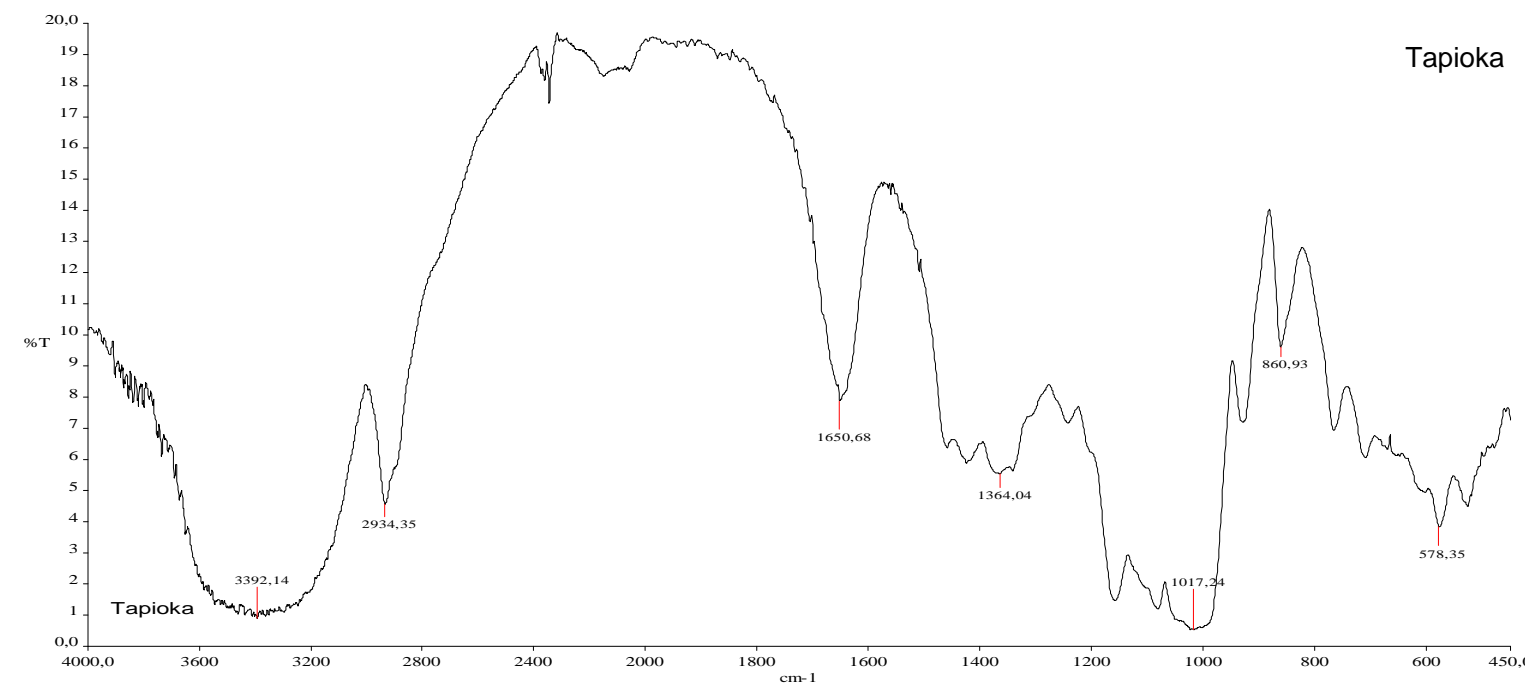

Gambar 8. Spektrum transmittance FTIR tapioka

Spektrum Campuran Antibiotik dan Tapioka

Apabila antibiotik dicampur dengan tepung tapioka, maka diperoleh hasil spektrum transmitance FTIR seperti ditunjukan pada Gambar 9 dan 10.

Spektrum FTIR campuran ampicillin dengan tepung tapioka tidak jauh berbeda dengan spektrum amoxicillin. Pada Gambar 9 terlihat beberapa puncak minimum pada bilangan gelombang tertentu. Puncak pada bilangan gelombang $3447 \mathrm{~cm}^{-1}$ menunjukan stretching vibrasi gugus $\mathrm{O}-\mathrm{H} ; 1775 \mathrm{~cm}^{-1}$ menunjukan stretching vibrasi gugus $\mathrm{C}=\mathrm{O}$; $1685 \mathrm{~cm}^{-1}$ menunjukan stretching vibrasi gugus $\mathrm{C}=\mathrm{C} ; 1578 \mathrm{~cm}^{-1}$ bending vibrasi $\mathrm{NH}$; $1485 \mathrm{~cm}^{-1}$ bending vibrasi $\mathrm{C}-\mathrm{H}$; 1090-1020 $\mathrm{cm}^{-1}$ untuk stretching vibrasi C-N; 1000-675 $\mathrm{cm}^{-1}$ bending vibrasi $\mathrm{C}-\mathrm{H}$; dan $556 \mathrm{~cm}^{-1}$ stretching vibrasi $\mathrm{C}-\mathrm{S}$.

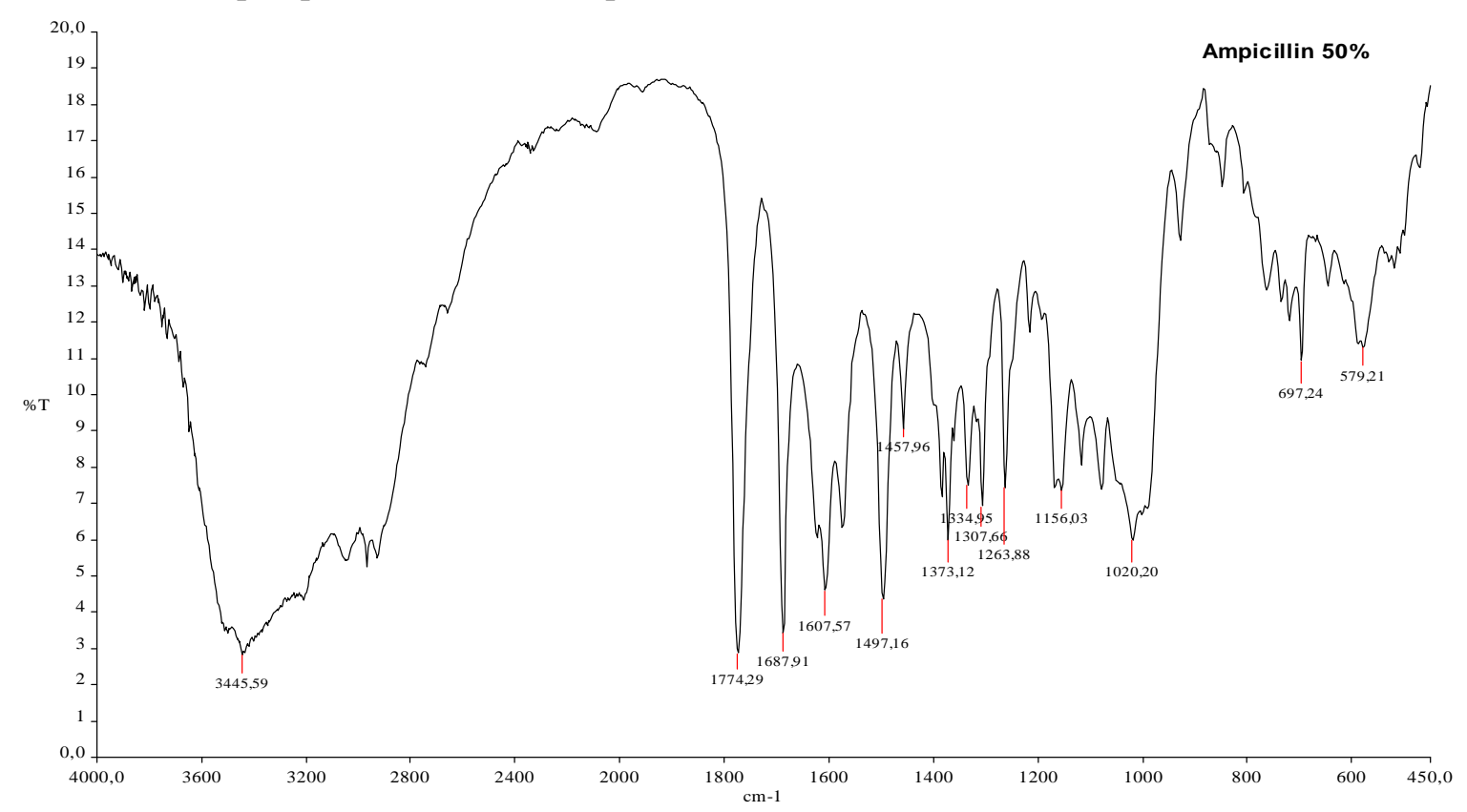

Gambar 9. Spektrum FTIR campuran ampicillin dan tapioka.

Untuk spektrum campuran amoxicillin (gambar 10) juga terdapat puncak yaitu pada bilangan gelombang $3445 \mathrm{~cm}^{-1}$ yang menunjukan stretching vibrasi $\mathrm{O}-\mathrm{H} ; 1774$ $\mathrm{cm}^{-1}$ menunjukan stretching vibrasi $\mathrm{C}=\mathrm{O}$; $1687 \mathrm{~cm}^{-1}$ stretching vibrasi $\mathrm{C}=\mathrm{C} ; 1607 \mathrm{~cm}^{-1}$ bending vibrasi $\mathrm{NH} ; 1350-1000 \mathrm{~cm}^{-1}$ stretching vibrasi $\mathrm{C}-\mathrm{C} ; \quad 1000-675 \mathrm{~cm}^{-1}$ 


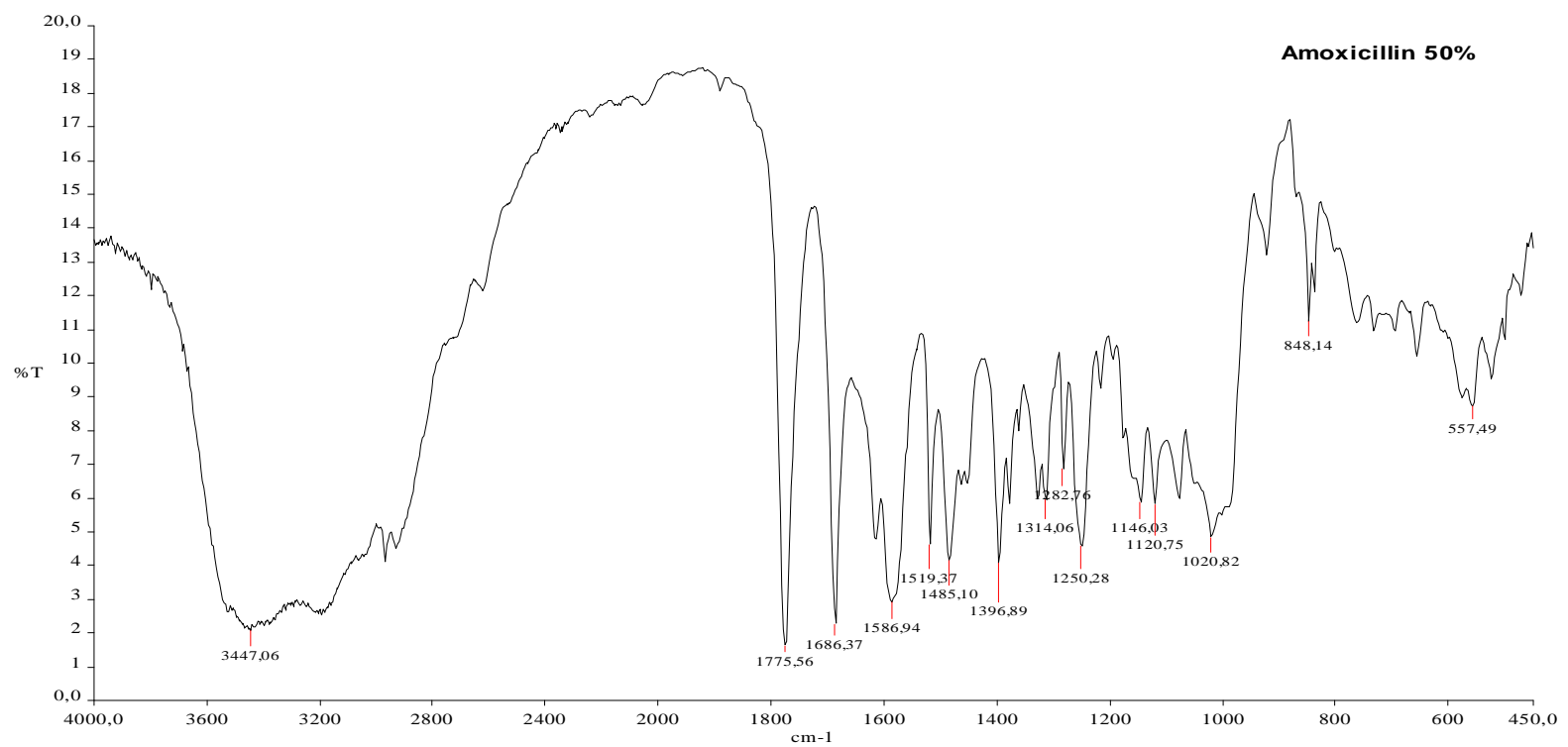

Gambar 10. Spektrum FTIR campuran amoxicillin dan tapioka.

bending vibrasi $\mathrm{C}-\mathrm{H}$; dan $579 \mathrm{~cm}^{-1}$ stretching vibrasi $\mathrm{C}-\mathrm{S}$.

Pengujian dan analisis dilakukan pula terhadap jenis antibiotik yang lain. Penelitian ini memberikan hasil bahwa setiap antibiotik memiliki pola spektrum FTIR yang spesifik. Harga bilangan gelombang yang sama untuk puncak spektrum transmittance FTIR pada beberapa jenis antibiotik menunjukan bahwa antibiotik tersebut memiliki gugus fungsi yang sama. Kesamaan ini tidak menunjukan bahwa rumus dan struktur molekul dari zat penyusun antibiotik akan sama pula, namun untuk mengetahui struktur molekulnya harus dilihat secara keseluruhan.

Data mengenai semua gugus fungsi dari masing-masing antibiotik dapat dipakai untuk menggambarkan bentuk struktur molekul dari zat yang dikandung dalam suatu antibiotik. Zat yang diperkirakan menjadi komponen penyusun antibiotik berdasarkan analisis spektrum XRD, terbukti memiliki gugus-gugus fungsi sama seperti hasil yang diperoleh melalui analisis spektrum FTIR. Informasi ini menunjukkan adanya konsistensi atau kesesuaian antara hasil yang diperoleh melalui pengukuran XRD dan FTIR.

Pencampuran tepung tapioka pada antibiotik memberikan informasi, bahwa ternyata harga bilangan gelombang pada campuran antibiotik merupakan gabungan dari harga bilangan gelombang yang dimiliki oleh masing-masing antibiotik dan tepung tapioka. Pengukuran spektrum FTIR tidak dapat digunakan untuk analisis kuantitatif mengenai tingkat kemurnian suatu zat penyusun antibiotik. Metode pengukuran FTIR hanya dapat digunakan untuk menentukan komposisi zat penyusun antibiotik sehingga dapat dibedakan jenis antibiotik yang satu dengan yang lain secara cepat.

\section{KESIMPULAN}

Pengukuran karakteristik difraksi sinar-x terhadap antibiotik menunjukan bahwa setiap antibiotik memiliki karakteristik yang berbeda. Perbedaan ini sesuai dengan analisis pengukuran spektrum infrared dengan FTIR yang digunakan untuk menentukan gugus fungsi zat penyusun antibiotik.

Pengukuran yang dilakukan dengan pencampuran antibiotik dengan tepung tapioka menunjukkan hasil bahwa pola spektrum yang dihasilkan merupakan gabungan masing-masing spektrum yang dimiliki oleh antibiotik dan tepung tapioka. Sayangnya, pola spektrum XRD dan FTIR tidak dapat memberikan informasi mengenai konsentrasi zat penyusun antibiotik secara kuantitatif.

Pengukuran dengan kedua peralatan tersebut dapat menjadi acuan sebagai metode analisis cepat untuk mengetahui komposisi zat penyusun antibiotik. Informasi ini dapat digunakan untuk identifikasi kandungan antibiotik satu dengan yang lain. 


\section{UCAPAN TERIMA KASIH}

Para peneliti secara bersama-sama ingin mengucapkan terima kasih kepada Rektor dan Ketua Lembaga Penelitian UIN Syarif Hidayatullah Jakarta yang telah memberikan kesempatan dan dana dalam pelaksanaan penelitian ini. Kami ucapkan terima kasih pula kepada segenap karyawan Pusat Laboratorium Terpadu UIN Jakarta atas segala bantuan dan kerjasama selama penelitian ini dilakukan.

\section{DAFTAR PUSTAKA}

1. Jozef V. Kolar, Radza Hromadova, 2007, Analysis of Antibiotic Utilization in Hospitalized Paedatric Patients. Journal of Chinese Medichine, vol.2, no.9, p.496503.

2. Subbiah Thangadurai, Sudhir Kumar Shukla, Asim Kumar Srivastava, and Yerramilli Anjaneyulu, 2003, X-Ray Powder Diffraction Patterns for Certain Fluoroquinolone Antibiotic Drugs. Acta Pharm. 53: 295-303.

3. Sambhaji Pisal, Rana Zainnuddin, Pradeep Nalawade, Kakasaheb Mahadik, and Shivajirao Kadam, 2004, Molecular Properties of Ciprofloxacin-Indion 234 Complexes. AAPS Pharm.Sci.Tech 5 (4) Article 62.

4. Hobby G. Penicillin: Meeting The Challenge. Yale University Press, New Haven, CT, 1985.

5. Sebastian A., Ed. Dates in Medichine: Chronological Record of Medical Progress Over Three Millenia. Parthenon, NewYork, 2000.

6. Frank A. Settle, 1997, Handbook of Instrumental Techniques for Analytical Chemistry: X-Ray Diffraction by Joseph Formica, p.339-364. Prentice Hall PTR, Upper Sandle River, New Jersey.

7. Charles Kittel, 1999, Intoduction to Solid State Physics (Seven Edition). John Willey and Sons Inc., Singapore,

8. Thomas R.M. Barends, Charles M.H. Hansgens, Jolanda J. Polderman-Tijmes, Peter A. Jekel, Erik de Vries, Dick B. Janssen, and Bauke W. Dijtkstra, 2003, X-Ray Analysis of Two Antibioticsynthesizing Bacterial Ester hydrolases:
Preliminary Results. Acta Cryst. D59: 158-160.

9. S. Thangadurai, J.T. Abraham, A.K. Srivastava, M. Nataraja Moorty, S.K. Shukla, and Y. Anjaneyulu, 2005, X-Ray Powder Diffraction Pattern for Certain $\beta$-Lactam, Tetracycline and Macrolide Antibiotic Drug. Analytical Sciences, vol. 21:833-838.

10. Shinobu Kobayashi, Hiroshi Nakai, Yuji Ikenishi, Wei-Yin Sun, Mamoru Ozaki, Yoshio Hayase, and Takeda, 1998, Micacocidin A, B, and C, Novel Antimycoplasma Agents from Pseudomonas sp. II Structure Elucidation. The Journal of Antibiotics 51: 328-332.

11. Alexandre T. Castro, 2006, NMR and FTIR Characterization of Petroleum Residues: Structural and Correlations. J.Braz.Chem.Soc., vol.17, no.6.

12. Dawit Solomon, Johannes Lehmann, James Kinyangi, Biqing Liang, and Thorsten Scafer, 2005, Carbon K-Edge NEXAFS and FTIR-ATR Spectroscopic Investigation of Organic Carbon Speciation in Soil. Soil Sci.Soc.Am.J. 69:107-119.

13. L.E. Rodriguez-Saona, N. Koca, W.J. Harper, and V.B. Alvarez, 2006, Rapid Determination os Swiss Chesse Compotition by Fourier Transform Infrared/ Attenuated Total Reflectance Spectroscopy. J.Dairy Sci. 89:1407-1412.

14. Michel E. Goldberg and Alain F. Chaffotte, 2005, Undistorted Structural Analysis of Soluble Proteins by Attenuated Total Reflectance Infrared Spectroscopy. Protein Science 14:27812792.

15. P. Whittaker, M.M. Mussoba, S. AlKhaldi, F.S. Fry, V.C. Dunkel, B.D. Tall, M.P. Yurawecz, 2003, Identification of Foodborne by Infrared Spectroscopy using Cellular Fatty Acid Methyl Esters. J. Microbiological Methods 55:709-716.

16. Harry G. Brittain, 2005, Solid-State Fluorescence of the Trihydrate Phases of Ampicillin and Amoxicillin. AAPS Pharm.Sci.Tech. 6 (3), article 55.

17. Alireza Ghassempour, Hasan Rafati, Laleh Adnasab, Yosef Bashour, Homeira 
Ebrahimzadeh, and Mohammad Erfan, 2007, Investigation of the Solid State Properties of Amoxicillin Trihydrate and the Effect of Powder pH. AAPS PharmSciTech 8 (4), article 93. 